\title{
Characterization of Publications on Burns in Brazil and Changes Resulting from Trauma in Brazil: Systematic Review of the Literature
}

Karen Rayara Bezerra Lima', Sara Porfirio de Oliveira1, Glória Catarina Beserra Rodriguez', Rayane Araújo do Nascimento1, Lívia Maria Nunes Henriques ${ }^{1}$, Kezauyn Miranda Aiquoc ${ }^{1}$, Ellen de Fátima Lima Vasconcelos ${ }^{1}$, José Joandson de Souza dos Santos ${ }^{1}$, Sabrina Daiane Gurgel Sarmento ${ }^{1}$, Rodrigo Assis Neves Dantas ${ }^{2}$, Daniele Vieira Dantas ${ }^{2}$, Ana Elza Oliveira de Mendonça², Katia Regina Barros Ribeiro², Maria do Carmo de Oliveira Ribeiro ${ }^{3}$, Isabelle Cristina Braga Coutinho Cunha4, Maria Marinah Souza do Nascimento ${ }^{5}$, Marília Rute de Souto Medeiros ${ }^{6}$, Vivianny Beatriz Silva Costa ${ }^{7}$, Beatriz da Silva Monteiro Cavalcanti ${ }^{8}$, Michele Carneiro Fonseca ${ }^{9}$, Luana Dinaiza Pinheiro de Medeiros ${ }^{10}$

\section{Abstract}

Objective: to conduct a systematic review of the literature on the characterization of publications on burns in Brazil and changes resulting from trauma

Methods and Results: The databases LILACS, BDENF, MEDLINE, SciELO and the Portal of Periodicals of CAPES were searched, according to the methodology of PRISMA (Preferred Reporting Items for Systematic Reviews and Meta-Analyzes). Data were collected following a structured script containing: author, database, year, type of study/approach, Journal, research place, gender, age, event location, etiologic agent, depth, the percentage of body surface burned and systemic changes caused by the burns. Of 49 studies identified, 16 met the inclusion criteria. Analyzing the sample for the event characteristics, it was observed a higher incidence of accidents in males. The main causes of burns were heated by liquid, followed by direct flame. Regarding the classification, the most frequent injury was the $2^{\text {nd }}$
1 Nursing Student at the Federal University of Rio Grande do Norte (UFRN).*

2 Ph.D. in Nursing. Associate Professor of the Department of Nursing of the Federal University of Rio Grande do Norte (UFRN).*.

3 Ph.D. in Nursing. Assistant Professor of the Department of Nursing at the Federal University of Sergipe (UFS). Aracaju/SE, Brazil.

4 Nurse at the municipality of Natal/ Rio Grande do Norte. Natal/RN, Brasil.

5 Nursing student at the UNIFACEX. Natal/RN, Brazil.

6 Nurse. Specialization Student Family Health with emphasis in Health/UFRN. *

7 Nursing student at the Federal University of Campina Grande. Campina Grande/PB, Brazil.

8 Medical student at the University Potiguar.*.

9 Nurse at the Maternity Divine Love. Rio de Janeiro/RJ, Brazil.

10 Nurse graduated from Federal University Rio Grande do Norte.*.

*: Natal/RN, Brazil.

Contact information:

Karen Rayara Bezerra Lima.

झ karen_rayara@hotmail.com 
degree, but also there were burns reports with mixed classification. Also, the upper limbs and trunk were the body parts most affected. In addition to these data, it was also highlighted the most frequent types of systemic changes caused by burns, which were respiratory complications, infection and/or sepsis and metabolic sequels.

Conclusion: The study showed the need to characterize of the publications in burns, since the crossing of this information provides a better understanding of the main causal factors, distribution and identification of risk groups. It also enables the planning of prevention strategies to help to reduce accidents, favoring the reduction of injuries and the number of hospitalizations. Moreover, it is extremely important that health professionals know about the epidemiological profile, to provide support in the evaluation and organization of care, and to prevention campaigns, aiming to decrease burn rates.

\section{Keywords}

Profile; Burns; Burn Units.

\section{Introduction}

Burning is an injury in the organ tissues that can be caused by thermal, chemical, radioactive, biological or electrical agents, with partial or complete tissue damage in the certain extension of the body surface. It can be classified according to the causative agent, depth, extent of body surface area burned, location, age, pre-existing conditions and associated lesions [1].

According to Leão et al. [2], the burns are still responsible for most of the injuries and deaths from external causes in Brazil. According to Montes, Barbosa and Sousa Neto [3], these events may be from industrial or domestic accidents, aggressions and suicide attempted. The most common causes of burns are a flame of fire and contact with boiling water, hot liquids and/or heated objects, and burns caused by electricity are less frequent.

The World Health Organization (WHO) estimated 195,000 deaths/year caused by burns in the world, and most of them occurred in low and middle-income countries. For this reason, child death is se- ven times higher in developing countries than in developed countries [4]. According to the WHO [4], there were approximately 1.4 million burn injuries annually in the United States, requiring 54,000 hospitalizations. Of this group, eight thousand people died by damages in the burned body areas and related inhalation injuries, being the fourth leading cause of death in that country.

In Brazil, the burns are a serious public health problem. Data of the Unified Health System (SUS) showed that 80,607 people were hospitalized for injuries from this type of trauma in 2009, accounting about $9 \%$ of the total group of hospitalizations of external causes in SUS, according to Gawryszewski et al. [5].

The Brazilian study of Gawryszewski et al. [5], analyzing 761 cases of burns seen in emergency services in several national states, found that most of the victims were male (58.6\%) and in the age group 30-49 years old (23.1\%), followed by the age group of zero to nine years old $(23.0 \%)$. The main agents were hot substances (43.6\%) and fire/flame (24.2\%). 
The costs of health care in the treatment of burns are high. According to the World Health Organization, the cost of hospitalization from burns only in the United States ranged from US $\$ 1,187$ and US\$ 4,102, being burn resulting from a fire. Also, readmissions and the need for a long-term rehabilitation also represent costs for children and their families, as well as absence from school, possible future unemployment, social rejection and other psychosocial aspects [4].

The treatment of burns is a challenge not only by the severity of the injuries but also for the many complications the burns bring. It is extremely important that health professionals know about the epidemiological profiles as a way to provide for the evaluation and organization of treatment regimens and prevention campaigns. Even with the lack of statistical data in Brazil, it is found the scientific basis information on some Burn Treatment Centers (CTQ), and have a profile that represents the status of the publications on the topic [6].

Faced with the above, it is clear the need to characterize of the publications in burns, since the crossing of this information provides a better understanding of the main causal factors, distribution and identification of risk groups, and also it enables the planning strategies prevention aimed at contributing to the reduction of accidents, favoring the reduction of injuries and the number of hospitalizations.

In this context, the aim of this study is to conduct a systematic review of the literature on the profile of scientific publications on burns in Brazil and systemic changes resulting from the trauma.

\section{Methods}

This is a retrospective and descriptive research, conducted according to the methodology Preferred Reporting Items for Systematic Reviews and MetaAnalyses (PRISMA) [7].

Data collection was carried out between April and May 2016 in the databases Latin American and Caribbean Center on Health Sciences (LILACS); Nursing Database (BDENF); Medical Literature Analysis and Retrieval System Online (MEDLINE), Scientific Electronic Library Online (SciELO) and the Journal Portal of Higher Education Personnel Improvement Coordination (CAPES). Manual searches were made in the references of the found articles.

The studies were investigated by the keywords "profile" and "burnt," according to the classification of the Health Sciences Descriptors (DeCS) using the Boolean operator "AND."

The inclusion criteria for the selection of publications were articles available in full; in Portuguese; and published between 2011 and 2015. The exclusion criteria were the studies that did not contemplate the purpose of the research and were repeated in more than one database.

Data were collected following a structured script containing: author, year, database, type of study/approach, Journal, research place, gender, age, event location, etiologic agent, depth, the percentage of body surface burned and systemic changes caused by the burns.

The information is shown in figure and tables, using descriptive statistics.

\section{Results}

After the elimination of 05 duplicate articles, 44 articles were selected. Of these, 18 were excluded after the analysis of titles and abstracts. Of the 26 eligible articles, 10 were excluded for the following reasons: 05 were treating about the profile of burn infections; 01 on the microbiological profile; and 01 dealt only with some specific symptom of injury. At the end, 16 studies were included in this systematic review [1-2, 8-21]. No studies were found through the manual search in the references of the articles found. Figure 1 presents the synthesis of the selection process of the articles.

After analysis, the publications were characterized as the author; database; year; type of study and approach; journal and research place (Table 1). 
Figure 1: Identification and selection flowchart of articles for systematic review on the characterization of publications on burns and changes resulting from trauma, Brazil, 2011 a 2015.

Studies identified from search in databases:

$$
\begin{aligned}
& \text { LILACS }=43 \\
& \text { MEDLINE }=1 \\
& \text { BDENF }=5 \\
& \text { Total }=49
\end{aligned}
$$

Removed duplicate articles

$$
\text { No. }=5
$$

Articles excluded after reading the abstracts

$$
\text { No. }=18
$$

Eligible articles

$$
\text { No. }=26
$$

Articles excluded after application of the exclusion criteria

$$
\text { No. }=10
$$

Studies included in the review

\begin{tabular}{|c|c|c|c|c|c|c|}
\hline Author & Year & Database & Type of Study & Approach & Journal & $\begin{array}{l}\text { Research } \\
\text { Place }\end{array}$ \\
\hline Dassie, Alves & $\begin{array}{c}2011 \\
{[1]}\end{array}$ & LILACS & $\begin{array}{l}\text { Cross-sectional } \\
\text { and retrospective }\end{array}$ & Quantitative & $\begin{array}{l}\text { Revista Brasileira de } \\
\text { Queimaduras }\end{array}$ & Paraná \\
\hline $\begin{array}{l}\text { Leão, Andrade,Fabrini, Oliveira, } \\
\text { Machado, Gontijo }\end{array}$ & $\begin{array}{c}2011 \\
{[2]}\end{array}$ & LILACS & Retrospective & Quantitative & $\begin{array}{l}\text { Revista Brasileira de } \\
\text { Cirurgia Plástica }\end{array}$ & $\begin{array}{l}\text { Minas } \\
\text { Gerais }\end{array}$ \\
\hline Reis, Moreira, Costa & $\begin{array}{c}2011 \\
{[8]}\end{array}$ & LILACS & $\begin{array}{l}\text { Retrospective and } \\
\text { descriptive }\end{array}$ & Quantitative & $\begin{array}{l}\text { Revista Brasileira de } \\
\text { Queimaduras }\end{array}$ & Sergipe \\
\hline $\begin{array}{l}\text { Serra, Guimarães Junior, Sperandio, } \\
\text { Stoffel, Zocrato, Neves }\end{array}$ & $\begin{array}{c}2011 \\
{[9]}\end{array}$ & LILACS & $\begin{array}{l}\text { Retrospective and } \\
\text { descriptive }\end{array}$ & Quantitative & $\begin{array}{l}\text { Revista Brasileira de } \\
\text { Queimaduras }\end{array}$ & $\begin{array}{l}\text { Rio de } \\
\text { Janeiro }\end{array}$ \\
\hline Cardoso, Orgaes, Gonella & $\begin{array}{l}2012 \\
{[10]}\end{array}$ & LILACS & Retrospective & Quantitative & $\begin{array}{l}\text { Revista Brasileira de } \\
\text { Queimaduras }\end{array}$ & São Paulo \\
\hline $\begin{array}{l}\text { Aragão, Aragão, Filgueira, Teixeira, } \\
\text { Reis }\end{array}$ & $\begin{array}{c}2012 \\
{[11]}\end{array}$ & LILACS & $\begin{array}{l}\text { Cross-sectional } \\
\text { and retrospective }\end{array}$ & Quantitative & $\begin{array}{l}\text { Revista Brasileira de } \\
\text { Queimaduras }\end{array}$ & Sergipe \\
\hline Espindula, Rocha, Alves & $\begin{array}{c}2013 \\
{[12]}\end{array}$ & LILACS & $\begin{array}{l}\text { Descriptive and } \\
\text { intervention }\end{array}$ & Quantitative & $\begin{array}{l}\text { Revista Brasileira de } \\
\text { Queimaduras }\end{array}$ & $\begin{array}{l}\text { Minas } \\
\text { Gerais }\end{array}$ \\
\hline Teodoro, Paiva & $\begin{array}{c}2013 \\
{[13]}\end{array}$ & LILACS & Cross-sectional & Quantitative & $\begin{array}{l}\text { Revista Brasileira de } \\
\text { Queimaduras }\end{array}$ & $\begin{array}{l}\text { Rio Grande } \\
\text { do Sul }\end{array}$ \\
\hline Camuci, Martins, Cardeli, Robazzi & $\begin{array}{c}2014 \\
{[14]}\end{array}$ & LILACS & $\begin{array}{l}\text { Explorative, } \\
\text { descritive, } \\
\text { retrospective }\end{array}$ & Quantitative & $\begin{array}{l}\text { Revista Cogitare } \\
\text { Enfermagem }\end{array}$ & Paraná \\
\hline $\begin{array}{l}\text { Serra, Sasaki, Cruz, Santos, } \\
\text { Paradela, Macieira }\end{array}$ & $\begin{array}{c}2014 \\
{[15]}\end{array}$ & LILACS & Retrospective & Quantitative & $\begin{array}{l}\text { Revista Brasileira de } \\
\text { Queimaduras }\end{array}$ & $\begin{array}{l}\text { Rio de } \\
\text { Janeiro }\end{array}$ \\
\hline
\end{tabular}

$$
\text { No. }=16
$$

\section{Exclusion reason:}

Infection profile (No. $=4$ )

Microbiological profile (No. $=1$ )

Specific symptoms (No. $=5$ )

Table 1. Characterization of publications about the author; year; database; type of study and approach; Journal and the research place. 


\begin{tabular}{|c|c|c|c|c|c|c|}
\hline Author & Year & Database & Type of Study & Approach & Journal & $\begin{array}{l}\text { Research } \\
\text { Place }\end{array}$ \\
\hline Alves e Silva, Faria, Maciel & $\begin{array}{c}2014 \\
{[16]}\end{array}$ & LILACS & Cross-sectional & Analytical & $\begin{array}{l}\text { Revista Brasileira de } \\
\text { Queimaduras }\end{array}$ & Goiás \\
\hline $\begin{array}{l}\text { Silva, Marques, Jorge, Andrade, } \\
\text { Lima, Andrade }\end{array}$ & $\begin{array}{c}2014 \\
{[17]}\end{array}$ & LILACS & Retrospective & Quantitative & $\begin{array}{l}\text { Revista Brasileira de } \\
\text { Queimaduras }\end{array}$ & São Paulo \\
\hline $\begin{array}{l}\text { Pedro, Rinaldi, Pan, Gonçalves, } \\
\text { Rossi, Farina Junior }\end{array}$ & $\begin{array}{c}2014 \\
{[18]}\end{array}$ & LILACS & $\begin{array}{l}\text { Descriptive and } \\
\text { retrospective }\end{array}$ & Quantitative & $\begin{array}{l}\text { Revista Brasileira de } \\
\text { Queimaduras }\end{array}$ & São Paulo \\
\hline Luz, Rodrigues & $\begin{array}{c}2015 \\
{[19]}\end{array}$ & LILACS & $\begin{array}{l}\text { Retrospective, } \\
\text { descriptive and } \\
\text { cross-sectional }\end{array}$ & Quantitative & $\begin{array}{l}\text { Revista Brasileira de } \\
\text { Queimaduras }\end{array}$ & São Paulo \\
\hline Marques, Amaral, Marcadenti & $\begin{array}{l}2015 \\
{[20]}\end{array}$ & LILACS & Prevalence & Quantitative & $\begin{array}{l}\text { Revista Brasileira de } \\
\text { Queimaduras }\end{array}$ & Alagoas \\
\hline $\begin{array}{l}\text { Biscegli, Benati, Faria, Boeira, Cid, } \\
\text { Gonsaga }\end{array}$ & $\begin{array}{c}2014 \\
{[21]}\end{array}$ & MEDLINE & $\begin{array}{l}\text { Cross-sectional } \\
\text { and retrospective }\end{array}$ & Quantitative & $\begin{array}{l}\text { Revista Paulista de } \\
\text { Pediatria }\end{array}$ & São Paulo \\
\hline
\end{tabular}

Regarding the databases, the one with most publications among the 16 articles found in full was the LILACS database with $93.7 \%$ of the articles. The period highlighted with a greater number of publications was 2014 (37.5\%) and 2011 (25.0\%). Regarding the approach used and the type of study, both aspects have obtained the same percentage (93.7\%) of scientific publications. Among the journals, the most prevalent were the articles published in the Revista Brasileira de Queimaduras (81.6\%). Regarding the regions developed in the research, there was prevalence in the Southeast (50.0\%) highlighting the state of São Paulo (25.0\%).

Regarding the clinical characterization and prevalence between genders, the average of the samples of each article was carried, since they had complete data. Those articles incomplete or without data were not considered for calculation purposes.

The age of patients varies, being elderly, adults, youth, and children patients. An average of 26.6 to 30 years old was obtained [2, 16-17, 20], over 60 $[9,15], 13$ to 59 years old $[8,10-11,19], 18$ to 76 years old [14], 0 to 18 years old [12, 21], and 0 to 12 years old $[1,11,18]$. Before the analyzed findings, the average age of patients with burns ranged from children and adults between 2 to 59 years old. The most prevalence gender was male (58.5\%).
Regarding clinical characteristics, the main etiological agents were thermal (82.2\%) and electrical $(12.8 \%)$. As the depth of the burns, the most prevalent were a $2^{\text {nd }}$ degree (42.5\%), 3rd degree burns $(23.2 \%)$ and mixed injury of $1^{\text {st }}$ and $2^{\text {nd }}$ degree (22.6\%). Also, the parts of the body that prevail in the studies are upper limbs, chest and legs, and the hand region of the body which affected the largest number of patients. It was also observed that the most affected victim was small burned (50.7\%) and major burn patients (28.8\%).

In addition to these data, the most frequent types of systemic changes caused by burns were shown, described in Table 2.

Regarding the systemic changes, $50.0 \%$ of 16 articles reported sequels caused by burns, and even

Table 2. Most frequent types of systemic changes caused by burns, cited by the studies.

\begin{tabular}{l|c|}
\multicolumn{1}{c|}{ Systemic Changes } & Reference \\
\hline Infection and/or sepsis & $1,19,20,21$ \\
\hline Respiratory sequels & $1,10,14,15,19,20$ \\
\hline Skin grafting and/or debridement & $17,19,21$ \\
Kidney failure & $15,19,20$ \\
Hypertrophic and/or hypotrophic scars & 17 \\
Metabolic sequels & 10 \\
Motor sequels & 10 \\
\hline Death & 19,20
\end{tabular}


more of one change in each study could be observed. The most prevalent changes were: respiratory sequels (75.0\%), infection and/or sepsis (50.0\%) and metabolic sequels (50.0\%).

\section{Discussion}

The burn injuries represent a significant problem to public health, with very high mortality rates for this type of injury [22]. When they do not lead to death, depending on the severity and level of commitment, they cause multiple sequels, both physical and/or psychological [23].

The main focus in the publications on Burns is in the epidemiology of cases, highlighting the etiology, depth, and extent of the burn, the affected area, its place and the systemic changes, as well as information about the assistance, such as length of stay and type of treatment [24].

In this study, there was a higher incidence of accidents by burns in men, according to the results obtained by Bessa et al. [25] in his study of the epidemiological profile of patients at the Regional Urgency and Emergency Hospital of Campina Grande, PB, in 2006. Besides, several studies developed in Brazil, both in general hospitals and in specialized treatment centers, indicate the male sex as the most frequently reached [26]. According to Nestor A and Turra K [27], men are more affected by these diseases by working in harsh services, being more exposed to traumas and accidents.

Burns by thermal agents (scalding and flames) were the main causes found, followed by accidents caused by electrical agents. The national literature cites similar data in a comprehensive manner [24]. And also the world literature places heat/fire as a first agent, followed by scalding [28]. For Balan et al. [26], the thermal agent is the major cause of burns, followed by chemical and electrical agents. Scalding accidents are associated with handling hot liquids in the home environment [2].
In this study, the body parts affected with a higher incidence were the upper limbs, anterior chest, and lower limbs. These findings are consistent with those described in studies of Leão et al. [2] and Dassie and Alves [1], according to which the main members were also the trunk and upper limbs.

According to Bessa et al. [25], the burns are classified according to gravity: light, moderate, and severe. The light burns are classified according to degrees: first degree - any extension of the body, second degree - less than $10 \%$ and third degree - less than 2\%. Moderate burns are classified in second degree between $10 \%$ and $20 \%$, and third degree - 5\%, while severe burns can present second degree - when above $20 \%$ on body surface area (BSA) and third degree- exceeding 10\% of BSA. In the study, lesions of $2^{\text {nd }}$ degree predominated, but also had reports of burns with mixed classification.

Based on the extent of burn, depth and specific types of injury, the Ministry of Health of Brazil, through Ordinance 1273, still classifies the victims of burn in small, medium or large burned [29]. As the frequency of the size of the burn, there was a predominance of the average burned patient when the higher prevalence of body surface area burned was $10 \%$ to $15 \%$.

In addition to these data, the most frequent types of systemic changes caused by burns were also evidenced, such as respiratory complications, infections, and motor sequels. Complications such as infection of injury, pneumonia, and acute renal failure are usually justified by the extent of BSA and depth of the burn. The higher the BSA, the greater the complications in the body homeostasis due to breakage of the barrier against infection by impaired skin integrity [20].

Based on this, it is a necessary investment in public health policies aimed at educating society in the prevention of trauma from burns. Not only with prevention but also combining more forms of first 
aid and treatment in case of accidents. Strategies should stimulate the safe and attentive practice for handling chemicals or flammable agents, the use of personal protective equipment as well as safety measures for adults and children against accidents at home.

\section{Conclusion}

According to the data analyzed in the study, articles indexed in the LILACS database and published in 2014 highlighted. Among the journals, the Revista Brasileira de Queimaduras had the highest number of published articles. In the territorial regions, there was a prevalence of cases in the Southeast, especially the state of São Paulo.

Regarding the clinical characterization of burns, it was observed a higher incidence of accidents in males. Even with the age of patients ranging from elderly, adults, youth and children, adults were the most affected.

The main causes of burns are by thermal agents, both accidents involving hot liquids or direct flame. The average burned body surface area (BSA) percentage ranged from $10 \%$ to $15 \%$. Regarding the classification, the most frequent degree of injury was the $2^{\text {nd }}$ degree, but also there were burns reported with mixed classification. The upper limbs and trunk are the body regions most affected.

In addition to these data, it was also evidenced the most frequent types of systemic changes caused by burns, such as respiratory complications, infection and/or sepsis and metabolic sequels.

The study showed the need to characterize of the publications in burns, since the crossing of this information provides a better understanding of the main causal factors, distribution and identification of risk groups. It also enables the planning of prevention strategies to help to reduce accidents, favoring the reduction of injuries and the number of hospitalizations. Moreover, it is extremely important that health professionals know about the epidemio- logical profile, providing support for the evaluation and organization of care, and prevention campaigns aiming to decrease burn rates.

\section{References}

1. Dassie LTD, Alves EONM. Centro de tratamento de queimados: perfil epidemiológico de crianças internadas em um hospital escola. Rev Bras Queimaduras. 2011; 10(1):10-14.

2. Leão CEG, Andrade ES, Fabrini DS, Oliveira RA, Machado GLB, Gontijo LC, et al. Epidemiologia das queimaduras no estado de Minas Gerais. Rev. Bras. Cir. Plást. 2011; 26(4): 573-7.

3. Montes SF, Barbosa MH, de Sousa Neto AL. Clinical and epidemiological aspects of burned patients hospitalized in a teaching hospital. Rev Esc Enferm USP. 2011; 45(2):369-73.

4. Organização Mundial da Saúde. [homepage na internet]. Available from: www.who.int.

5. Gawryszewski VP, Bernal RTI, Silva NN, Morais Neto OL, Silva MMA, Mascarenhas MDM, et al. Atendimentos decorrentes de queimaduras em serviços públicos de emergência no Brasil, 2009. Cad Saude Publica. 2012; 28(4):629-40.

6. Coutinho BBA, Balbuena MB, Anbar RA, Anbar RA, Almeida KG, Almeida PYNG. Perfil epidemiológico de pacientes internados na enfermaria de queimados da Associação Beneficente de Campo Grande Santa Casa/MS. Rev Bras queimaduras 2010; 9(2):50-53.

7. Moher D, Liberati A, Tetzlaff J, Altman DG, PRISMA Group. Preferred reporting items for systematic reviews and metaanalyses: the PRISMA statement. Ann Intern Med. 2009; 151(4):264-9.

8. Reis IF, Moreira CA, Costa ACSM. Estudo epidemiológico de pacientes da unidade de tratamento de queimados do hospital de urgência de Sergipe. Rev Bras Queimaduras. 2011; 10(4):114-8.

9. Serra MC, Guimarães Junior LM, Sperandio A, Stoffel C, Zocrato K, Neves L, et al. Queimadura em pacientes da terceira idade: epidemiologia de 2001 a 2010. Rev Bras Queimaduras. 2011; 10(4):111-3.

10. Cardoso L, Orgaes FS, Gonella HA. Estudo epidemiológico das queimaduras químicas do CTQ-Sorocaba. Rev Bras Queimaduras. 2012; 11(2):74-9.

11. Aragão JÁ, Aragão MECS, Filgueira DM, Teixeira RMP, Reis FP. Estudo epidemiológico de crianças vítimas de queimaduras. Rev Bras Cir Plást. 2012; 27(3):379-82.

12. Espindula AP, Rocha LSM, Alves MO. Perfil de pacientes queimados do Hospital de Clínicas. Rev Bras Queimaduras. 2013; 12(1):16-21. 
13. Teodoro AL, Paiva VS. Pacientes queimados admitidos em um serviço terciário de Caxias do Sul. Rev Bras Queimaduras. 2013; 12(2):108-11.

14. Camuci MB, Martins JT, Cardeli AAM, Robazzi MLCC. Caracterização epidemiológica de pacientes adultos internados em uma unidade de terapia intensiva de queimados. Cogitare Enferm. 2014 Jan/Mar; 19(1):78-83.

15. Serra MCVF, Sasaki AL, Cruz PFS, Santos AR, Paradela EMP, Macieira L. Perfil epidemiológico de idosos vítimas de queimaduras. Rev Bras Queimaduras. 2014; 13(2):90-4.

16. Alves e Silva GM. Faria GL, Maciel MA. Perfil epidemiológico dos pacientes atendidos no Pronto-Socorro de Queimaduras de Goiânia em agosto de 2013. Rev Bras Queimaduras. 2014; 13(3):173-6.

17. Silva LA, Marques EGSC, Jorge JLG, Andrade CZN, Lima RVKS, Andrade GAM, et al. Pacientes com sequelas de queimaduras atendidos na Unidade de Queimados do Hospital das Clínicas da Faculdade de Medicina de Ribeirão Preto. Rev Bras Queimaduras. 2014; 13(3):168-72

18. Pedro ICS, Rinaldi ML, Pan R, Gonçalves N, Rossi LA, Farina Junior JA, et al. Hospitalizações para o tratamento agudo de crianças e adolescentes queimados. Rev Bras Queimaduras. 2014; 13(3):154-60.

19. Luz SSA, Rodrigues JE. Perfis epidemiológicos e clínicos dos pacientes atendidos no centro de tratamento de queimados em Alagoas. Rev Bras Queimaduras. 2014; 13(4):245-50.

20. Marques MD, Amaral V, Marcadenti A. Perfil dos pacientes grandes queimados admitidos em hospital de trauma. Rev Bras Queimaduras. 2014; 13(4):232-5.

21. Biscegli TS, Benati LD, Faria RS, Boeira TR, Cid FB, Gonsaga RAT. Perfil de crianças e adolescentes internados em Unidade de Tratamento de Queimados do interior do estado de São Paulo. Rev Paul Pediatr. 2014; 32(3) 177-182.

22. Brasil. Ministério da Saúde. Secretaria de Atenção à Saúde. Departamento de Atenção Especializada. Cartilha para tratamento de emergência das queimaduras. Brasília: Editora do Ministério da Saúde, 2012. 20 p.: il.

23. Fernandes FMFA, Torquato IMB, Dantas MSA, Pontes JFAC, Ferreira JA, Collet N. Queimaduras em crianças e adolescentes: caracterização clínica e epidemiológica. Rev. Gaúcha Enferm. [Internet]. 2012 Dec [cited 2016 July 01]; 33(4): 133-141. Available from: http://www.scielo.br/scielo.php?script=sci arttext\&pid=S1983-14472012000400017\&lng=en.

24. Cruz BF, Cordovil PBL, Batista KNM. Perfil epidemiológico de pacientes que sofreram queimaduras no Brasil: revisão de literatura. Rev Bras Queimaduras. 2012; 11(4):246-250.
25. Bessa DF, Ribeiro ALS, Barros SEB, Mendonça MC, Bessa IF, Alves MA, et al. Perfil epidemiológico dos pacientes queimados no Hospital Regional de Urgência e Emergência de Campina Grande, PB, Brasil. Rev Bras Ciênc Saúde. 2006; 10(1):73-80.

26. Balan MAJ, Oliveira MLF, Trassi G. Características das vítimas de queimaduras atendidas em unidade de emergência de um hospital escola do noroeste do Paraná. Cienc Cuid Saúde. 2009; 8(2):169-75.

27. Nestor A, Turra K. Perfil epidemiológico dos pacientes internados vítimas de queimaduras por agentes inflamáveis. Rev Bras Queimaduras. 2014; 13(1):44-50.

28. Dias LDF, Oliveira AF, Juliano Y, Ferreira LM. Unidade de Tratamento de Queimaduras da Universidade Federal de São Paulo. Rev. Bras. Cir. Plást. 2015; 30(1):86-92.

29. Ministério da Saúde (Brasil). Portaria $n^{\circ}$ 1.273, de 21 de novembro de 2000. Estabelece mecanismos para a organização e implantação de Redes Estaduais de Assistência a Queimados. Available from: http://www.saude.mg.gov.br/ index.php?option=com gmg\&controller=document\&id $=890$ portaria-gm-ms-n\%C2\%BA-1273-de-21-11-2000-sesmg.

\section{Publish in International Archives of Medicine}

International Archives of Medicine is an open access journal publishing articles encompassing all aspects of medical science and clinical practice. IAM is considered a megajournal with independent sections on all areas of medicine. IAM is a really international journal with authors and board members from all around the world. The journal is widely indexed and classified Q2 in category Medicine. 